\title{
Utilizing Social Media in Vocabulary Enhancement among Primary ESL Learners
}

\author{
Sutasini Sivagnanam ${ }^{1, *}$, Melor Md Yunus ${ }^{2}$ \\ ${ }^{1}$ Sekolah Kebangsaan Batu Kikir, Negeri Sembilan, Malaysia \\ ${ }^{2}$ Faculty of Education, Universiti Kebangsaan Malaysia, Malaysia \\ Received November 23, 2019; Revised January 6, 2020; Accepted January 13, 2020
}

Copyright $\odot 2020$ by authors, all rights reserved. Authors agree that this article remains permanently open access under the terms of the Creative Commons Attribution License 4.0 International License

\begin{abstract}
ICT is one of the main mediums used in and out of classroom since Malaysian education system focuses on $21^{\text {st }}$ century learning. This study aims to investigate how pupils utilize social media to improve their vocabulary and possible challenges faced when using social media as a medium to learn vocabulary. The respondents of this quantitative study comprise of 53 nine and ten-year-old students. The respondents were selected using purposive sampling method from a school in Batu Kikir, Negeri Sembilan. The questionnaire consist of 6 sections and the final section was divided into 3 parts according to the themes, the first part measured to see if students utilized the features available in social media, followed by challenges and finally motivation factor. The findings show that students utilize features on social media as an effective way to learn vocabulary and social media acts as a motivating factor for primary ESL learners to learn vocabulary. The result of this study could be useful for future research for English as Second Language Learners. Focus for further research can be about the challenges faced by students when using social media to develop vocabulary.
\end{abstract}

Keywords ESL Learners, Social Media, Vocabulary, Motivation

\section{Introduction}

Language learning has turned into something that happens out of classroom and not just in the four walls of a classroom [1]. Social networking plays a pivotal role in education which includes young learners who are exposed to the use of social media at a very young age. The Malaysian education system focuses on $21^{\text {st }}$ century learning to ensure students are well equipped with the knowledge of ICT and aware of the opportunity that they can seize using mediums such as social media and social networking sites. Incorporation of social media in education has been taken seriously by educators nowadays. Thus, Malaysian Education system is actively focusing on creating learners who can work independently in forming their own knowledge even in out-of-class context. As stated by Yunus, et. al. [5] most students spend a considerable amount of time in using social media. Students scan for information, socialize, gain knowledge and use social media for entertainment purposes. This statement shows that students are working towards gaining knowledge independently with the presence of social media. Even so, social media use is constantly criticized for affecting students' efficiency, academic writing as well as their grades [30] be in Malaysia or other parts of the world. This could be due to excessive use of slang words online. The popularity of social media use among students has raised the interest of language teachers around the globe in exploring the potential of utilizing social media in certain aspects of language learning. One of the areas of language learning that can benefit from using social media is vocabulary.

In a study conducted on social networks and their effectiveness in learning foreign language vocabulary [6], even after using social media, there were no stated differences between the control and experimental group. This result contradicts the findings of other previous studies [7-9]. The findings of the studies [7-9] shows significant improvement in students' vocabulary when they are exposed to social media use. This contradicting result is a major reason on why this study was conducted in Malaysian Primary ESL learners' context. Despite having many researches being carried out, most of these studies are based on data collected from secondary and tertiary education level and there is surprising lack of empirical research which focuses on the impact of social media among primary ESL learners in Malaysia. Very few studies also focused on the impact of social media specifically in primary ESL learners' way of building their vocabulary. A study conducted by Jafari \& Chalak [7] also suggested to look into students' proficiency level before conducting a research and social media cannot be regarded superior to classroom learning but study shows participants are more comfortable in engaging themselves in an online discussion rather than face-to-face method as it creates an informal learning 
environment that lowers their affective filter such as anxiety [8].

There are also two approaches to vocabulary learning. The approaches are explicit and incidental learning. This approaches also works as foundation behind students approaches to vocabulary learning. According to Schmitt, [38] incidental learning can be defined as learning without intention or subconsciously whereas, explicit learning means learning that takes place while the learner is focused on the task. In this study, social media as incidental vocabulary learning technique will be analyzed. Hunt and Beglar [39] stated that incidental vocabulary learning is a useful way to acquire vocabularies for advanced learners whereas intentional/explicit learning is highly important for beginners.

Previous studies [7,9] used mixed method with pre-test, post-test and semi-structured interview in their study. On the other hand, Dehghan, Rezvani and Fazeli [6] used quantitative research method with quasi-experimental design by using pre-test and post-test data to answer their research questions, whereas Vikneswaran and Krish [9] used qualitative research method such as document analysis and semi-structured interview. Most researches focused more on students, academic performance and motivation factors. Thus, this study is carried out to find out on how students utilize social media and the features in order to learn vocabulary. Researcher believes that, only by knowing the way students utilize social media can help in creating other strategies using social media. This study also focuses on challenges that they might face and finally the motivation factor. None of the research mentioned focused on any rural schools. This adds to the reason to conduct this study in a rural school where the internet connectivity is limited in some areas.

Based on the considerations, there are three target research questions which will be discussed

1. Do students utilize social media features in developing vocabulary?

2. Do students face challenges when using social media to learn vocabulary?

3. Does using social media motivate students to learn new vocabulary?

\section{Krashen's Second Language Acquisition Theory}

According to Krashen's (1985) Input Hypothesis (as cited in Cabrera [25]) people learn the language through their exposure to input or reading text. His theory of second language acquisition consists of a set of five (5) hypotheses, namely: The acquisition learning hypothesis, monitor hypothesis, input hypothesis, natural order hypothesis, and affective filter hypothesis [18]. According to Krashen's comprehensible input hypothesis "if input is understood, and there is enough of it, the necessary grammar is automatically provided". In, other words, L2 learners acquire language when they are provided with comprehensible input. Researcher believes that social media acts as a medium in making input comprehensible thus allowing students to acquire it subconsciously. For example, students will be able to pick up new vocabulary from comments, spell-check feature, "search google for" feature, games on social media and by communicating with other users through chats. This is supported by Bytheway [34] who believes that many language learners use computer games as informal learning context. Krashen's affective filter hypothesis focuses on creating environment to lower one's anxiety level to motivate them to learn with ease. According to [9], respondents stated that they feel more confident and motivated to learn vocabulary when using social media as it creates an environment that does not involve face-to-face interaction. Figure 1 shows the relationship between the theory and social media use in learning vocabulary.

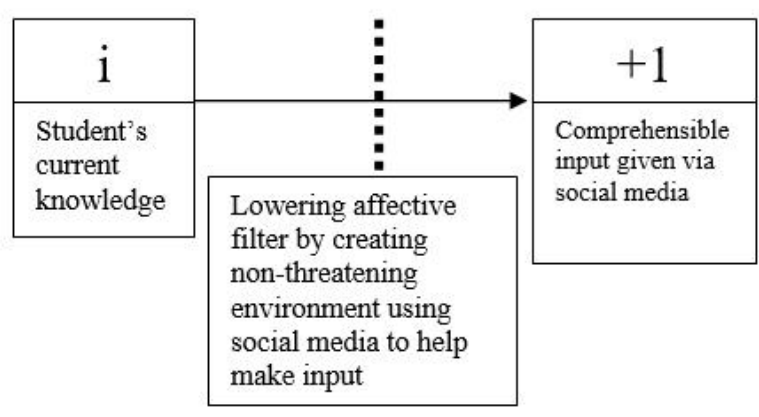

Figure 1. The input Hypothesis \& Affective filter Hypothesis

\section{Social Media and Language Learning}

The term social media can be referred to as web-based services that provides opportunity for individuals to form their own profile page and connect with people through mutual friends or even their preferred users [2]. According to Faizi, Afia and Chiheb (2013) [16] social media also brings people with common interest together to share their moments, photos, videos and events. It is a platform for people to connect with one another regardless of age and time. Social media provides a huge amount of material on a wide range of subjects. Students can therefore turn to any of these tools for further explanations or clarifications. It helps learners to access information and to have control over their learning [17]. They also get to choose on the type of materials they wish to access to learn. Currently, the most popular of these social medias is Facebook [1]. The wide range of use suggested, is one of the main reasons why this study focuses on how students actually make use of the features on social media for academic purposes. Mensah and Nizam [4] concluded that social media platforms have a significant impact on students' academic performance in Malaysian tertiary institutions. On another study conducted, the author says that social networking sites help students do significantly better in school, primarily through utilizing connecting with each other on school assignments and collaborative group projects outside of class. It can be further confirmed that connecting with one another via social media features such as chat helps to improve informal learning [3]. It is supported by Greenhow and Lewin [10], who believe social media has the potential to bridge formal 
and informal learning through participatory digital cultures. For this reason, the researcher believes social media has vast possibility as an educational tool based on the available features.

\section{Social Media and Vocabulary Learning}

Vocabulary learning is said to be one of the most important part of language learning and it is often seen as an important tool for second language learning. It is also supported by Alqahtani [27] and Tehranian [28] who believe vocabulary learning is an integral part of language pedagogy and it is an indispensable part of language learning. Therefore, teaching and learning of vocabulary must be carried out in the right way. Learning is a socially mediated process [26] and it is directly derivative to their exposure to the environment [25]. The core assumption here is that, social media serves the purpose of creating social interaction and exposure to the virtual environment. There are some common strategies to build vocabulary reported in empirical research such as (1) repeated exposure as mentioned by Hairell et. al [14], followed by (2) creativity and (3) collaboration with a wide range of commentators [3]. When using social media, students are given the chance to learn vocabulary by using strategies such as collaborating with other social media users in comment sections and this will provide an opportunity for them to learn new words. Repeated exposures in social media occur when students get to look at the words constantly and they tend to remember the word subconsciously. Words such as profile, comment, like and post are some of the examples of words that are repeatedly exposed when using social media such as Facebook. Hence, teaching and learning through interaction is said to be one of the best ways to develop vocabulary. Given their extensive exposure to screens, Tehranian [28], believes learners may spend less time in face-to-face communication so the proper utilization of social media features to learn vocabulary will be studied.

\section{Challenges in Using Social Media in Learning Vocabulary}

Mahalingam and Yunus [11] emphasized that learners employ various language learning strategies to facilitate their learning of the language and improve their proficiency level. Early vocabulary development is deemed important for young learners. Oral vocabulary is usually acquired by most children through interaction with their peers, parents and siblings as cited in Beck, Mckeown and Kucan [13]. Social media here is seen as a learning strategy to facilitate their learning and bridging the gap by interacting with people around the world but there are always some drawbacks in any strategy. One limitation is that when a person picks up inappropriate and incorrect form of language from others in social media. According to Cabrera [25] when students use social media as a means of learning they tend to get used to wrong spelling and internet slang words as stated in a study by James [22], sometimes students find themselves using the short forms of words when writing English assignments. The usage of abbreviations or acronyms to save time might affect the quality of formal write up or even create possible spelling errors that might affect the vocabulary learning process and students are concerned about the safety and security issues with the use of social media [20]. The fact that some social media users tend to underperform academically is also supported by Roopchund [20] who believes, there is a negative association between social media use and academic performance, and it is important point to look into than focusing on its advantages alone. Parents are often worried when kids spend time gaming on social media as they believe it might affect their language learning, but a research conducted by Cabrera [25] proves otherwise. Gaming on social media also helps in language learning in a positive way. According to Cabrera [25] when socio-emotional messages are being exchanged among gamers, the players are said to give more positive messages than negative ones. Therefore, the effects of the mentioned challenges to the respondents from primary ESL learners will be discussed in the analysis section. When recognizing these challenges, it can actually help in reducing certain threats such as ethical threat and can at least be moderated [35].

\section{Social Media and Motivation to Learn}

The concept of motivation can be defined as a force which causes people to behavior particularly [15]. Motivation can be divided into two major groups, namely intrinsic and extrinsic. When compared, intrinsic motivation has been proven to predict desirable outcome in terms of output quality which includes academic performances [29]. Learners' motivation of learning vocabulary is an important factor which influences the use of their effective learners' strategies [21]. Motivation here serves as a major factor to assist students' learning. this can be seen as some researchers have proven that groups that received engagement and motivation through the use of social media had actually shown better outcome in an English proficiency test compared to the group that received education on a face-face basis [23] and a participant of another research said that, there is a lot of expression slangs or acronyms that they can never learn from their textbooks and social media helps them utilize the language more naturally and efficiently [25]. Consequently, researcher decided to further analyze if social media helps learners gain intrinsic motivation to develop vocabulary.

\section{Methodology}

\section{Sampling}

This study was conducted in a rural primary school in Batu Kikir Malaysia. It comprises of year 4 and year 5 students who are second language learners of English. Since the school has $100 \%$ Malay students, their first language is Bahasa Malaysia. The use of English is very much limited and usually used only during English lesson for learning 
purposes. This arises the concern to constantly study on ways students can utilize sources other than books in order to develop their vocabulary. The participants were chosen using purposive sampling method. 31 year 5 students and 22 year 4 students were selected as participants of this study. The participants are of intermediate proficiency level and can communicate in simple English. All the participants come from a background where Bahasa Melayu is their preferred spoken language at home.

Krejcie and Morgan (1970) sampling size was used to select the participants. Based on the population, $\mathrm{N}=61$ the suggested sampling size is $S=53$. Thus, the total population was chosen based on intermediate language proficiency students from primary 4 and primary 5. 53 students were selected for this study. Convenience sampling technique was used to select the respondents of this survey as all the students from year 4 and year 5 intermediate proficiency class were selected. The students were already streamed according to their level of achievement.

\section{Instrumentation}

The data was collected using a questionnaire. The questionnaire used in this study was developed by the researcher. In this study, the researchers develop the questionnaires based on literature on social media and its application for educational purposes. Before questionnaires were sent to respondents, an English language expert was asked to check the words and expressions. Then 3 respondents were chosen for further pilot study for any misunderstanding of the language. The questionnaire was finalized subsequent to a double check of language and wording.

The questionnaire was divided into 6 sections. Section A consists of respondents' demographic profiles which includes gender, primary and duration of social media use. Section B includes 5 items focusing on respondents' access to ICT tools. Section $C$ has 10 items to measure the frequency of social media use, Section E (12 items) with four-point Likert scale to gather data on factors affecting the use of social media. Finally, Section F (10 items) was divided into 3 major themes. Item 1-6 to measure the perception of respondents in using social media for vocabulary learning, item 7 and 8 to measure challenges faced by respondents when social media is used to learn vocabulary and item 9 and 10 to find out if social media motivates pupils to learn new vocabulary.

\section{Findings and Discussion}

\section{Demographic Profile of Respondents}

The demographic analysis emphasized on three key variables which are gender, primary and duration of social media use.

Table 1 shows the gender distribution among the respondents. $37 \%$ of the respondents are male and $62.3 \%$ are female. The difference in sampling is due to the percentage of female student population in intermediate proficiency level is higher than the percentage of male students.

Table 1. Number of respondents according to gender.

\begin{tabular}{ccc}
\hline Gender & N & Percentage (\%) \\
\hline Male & 20 & 37.7 \\
\hline Female & 33 & 62.3 \\
\hline Total & 53 & 100 \\
\hline
\end{tabular}

Table 2. Duration of using Social Media

\begin{tabular}{ccc}
\hline Age & Frequency & Percentage (\%) \\
\hline $\mathbf{1 - 3}$ & 0 & 0 \\
\hline $\mathbf{4 - 6}$ & 1 & 1.9 \\
\hline $\mathbf{7 - 9}$ & 49 & 92.4 \\
\hline $\mathbf{1 0 - 1 1}$ & 3 & 5.7 \\
\hline Total & 53 & 100 \\
\hline
\end{tabular}

Table 2 shows the duration of social media use by the respondents. Majority of respondents from primary 4 and primary 5 started using social media at the age of 7-9 $(92.4 \%)$. This data is considered relevant as the respondents are of 10 and 11 years old. This sums up that, most respondents have been using social media for an average of 2 to 3 years. Keeping in mind their competency level might be of a beginner's level.

Table 3. Primary

\begin{tabular}{ccc}
\hline Primary & Frequency & Percentage (\%) \\
\hline $\mathbf{4}$ & 22 & 41.5 \\
\hline $\mathbf{5}$ & 31 & 58.5 \\
\hline Total & 53 & 100 \\
\hline
\end{tabular}

The respondents are selected from year 4(10 years old $)$ and year 5 (11 years old). There were 22 respondents from year 4 and 31 respondents from year 5 . The respondents were all of intermediate language proficiency level.

Table 4. Access to ICT tools

\begin{tabular}{|c|c|c|c|c|}
\hline \multirow[t]{2}{*}{ Item } & \multirow[t]{2}{*}{$\begin{array}{c}\text { Access to ICT } \\
\text { tools }\end{array}$} & \multicolumn{2}{|c|}{$\begin{array}{c}\text { Frequency / } \\
\text { percentage }(\%)\end{array}$} & \multirow[t]{2}{*}{ Mean } \\
\hline & & YES & NO & \\
\hline B1 & $\begin{array}{l}\text { Do you have } \\
\text { access to } \\
\text { computer? }\end{array}$ & $\begin{array}{c}34 \\
(64.2)\end{array}$ & $\begin{array}{c}19 \\
(35.8)\end{array}$ & 1.36 \\
\hline B2 & $\begin{array}{l}\text { Do you have } \\
\text { access to } \\
\text { smartphone? }\end{array}$ & $\begin{array}{c}45 \\
(84.9)\end{array}$ & $\begin{array}{c}8 \\
(53.0)\end{array}$ & 1.15 \\
\hline B3 & $\begin{array}{c}\text { Do you have } \\
\text { access to } \\
\text { iPad? }\end{array}$ & $\begin{array}{c}32 \\
(60.4)\end{array}$ & $\begin{array}{c}21 \\
(39.6)\end{array}$ & 1.40 \\
\hline B4 & $\begin{array}{c}\text { Do you have } \\
\text { access to internet? }\end{array}$ & $\begin{array}{c}49 \\
(92.5)\end{array}$ & $\begin{array}{c}4 \\
(7.5)\end{array}$ & 1.08 \\
\hline \multirow[t]{2}{*}{ B5 } & $\begin{array}{c}\text { Do you use social } \\
\text { media actively? }\end{array}$ & $\begin{array}{c}42 \\
(79.2)\end{array}$ & $\begin{array}{c}11 \\
(20.8)\end{array}$ & 1.21 \\
\hline & Mean of Total & & & 1.24 \\
\hline
\end{tabular}

Item B1 shows that 34 out of $53(64.2 \%)$ of respondents have access to computer. Item B2 and B3 shows that more than half of the respondents agreed that they have access to smart phones (84.9\%) and iPad (60.4\%). Respondents are more inclined to the usage of smartphone and iPad rather than computer. Smartphones have increased the ease of use 
and ease of access. This is proven by item B4 which shows that $92.5 \%$ of respondents have access to internet. Internet access is made easy with mobile data. B5 shows $79.2 \%$ respondents use social media actively whereas $20.8 \%$ use it only occasionally. The mean total with a value of 1.24 also shows that majority of respondents have answered Yes for almost all the items.

Table 5 was used to show the list of social media and frequency of use. According to the results obtain, it can be seen that the most frequently used social media is YouTube with $54.7 \%$ answering "always" as their option followed by WhatsApp sharing the same percentage, 54.7\%. YouTube is considered the most famous social media among the respondents with the mean value of responses $M=3.42$. This can also be supported with the result obtained from Table 4, item B2 and B3 where most respondents have access to smartphones and iPad. The easily accessible application on smartphones can be the reason why respondents prefer using WhatsApp and YouTube whereas Facebook and other social media may require them to set up a profile before using it. This is also supported by Inzamul [30] who believes social media is not limited to desktop or laptop computers but could be accessed through mobile applications and smart phones making it very accessible and easy to use. With that, social media can also use as a medium to transform role of teachers from knowledge provider to facilitator of learning if social media is utilized well as stated by Yunus et. al. [33].

Table 5. Use of Social Media

\begin{tabular}{|c|c|c|c|c|c|c|}
\hline \multirow[t]{2}{*}{ Social Media } & \multicolumn{4}{|c|}{ Frequency / percentage (\%) } & & \multirow[t]{2}{*}{ Mean } \\
\hline & N.A & Weak & Moderate & Good & Very good & \\
\hline Facebook & $\begin{array}{c}23 \\
(43.4)\end{array}$ & $\begin{array}{c}3 \\
(5.7)\end{array}$ & $\begin{array}{c}7 \\
(13.2)\end{array}$ & $\begin{array}{c}10 \\
(18.9)\end{array}$ & $\begin{array}{c}10 \\
(18.9)\end{array}$ & 2.64 \\
\hline Twitter & $\begin{array}{c}43 \\
(81.1)\end{array}$ & $\begin{array}{c}3 \\
(5.7)\end{array}$ & $\begin{array}{c}2 \\
(3.8)\end{array}$ & $\begin{array}{c}3 \\
(5.7)\end{array}$ & $\begin{array}{c}2 \\
(3.8)\end{array}$ & 1.45 \\
\hline WeChat & $\begin{array}{c}42 \\
(79.2)\end{array}$ & $\begin{array}{c}3 \\
(5.7)\end{array}$ & $\begin{array}{c}2 \\
(3.8)\end{array}$ & $\begin{array}{c}5 \\
(9.4)\end{array}$ & $\begin{array}{c}1 \\
(1.9)\end{array}$ & 1.49 \\
\hline LINE & $\begin{array}{c}44 \\
(83.0)\end{array}$ & $\begin{array}{c}2 \\
(3.8)\end{array}$ & $\begin{array}{c}3 \\
(5.7)\end{array}$ & $\begin{array}{c}4 \\
(7.5)\end{array}$ & $\begin{array}{c}0 \\
(0.0)\end{array}$ & 1.38 \\
\hline Instagram & $\begin{array}{c}19 \\
(35.8)\end{array}$ & $\begin{array}{c}3 \\
(5.7)\end{array}$ & $\begin{array}{c}6 \\
(11.3)\end{array}$ & $\begin{array}{c}11 \\
(20.8)\end{array}$ & $\begin{array}{c}14 \\
(26.4)\end{array}$ & 2.96 \\
\hline YouTube & $\begin{array}{c}0 \\
(0.0)\end{array}$ & $\begin{array}{c}3 \\
(5.7)\end{array}$ & $\begin{array}{c}5 \\
(9.4)\end{array}$ & $\begin{array}{c}12 \\
(22.6)\end{array}$ & $\begin{array}{c}33 \\
(62.3) \\
\end{array}$ & 4.42 \\
\hline WhatsApp & $\begin{array}{c}4 \\
(7.5)\end{array}$ & $\begin{array}{c}1 \\
(1.9)\end{array}$ & $\begin{array}{c}4 \\
(7.5)\end{array}$ & $\begin{array}{c}17 \\
(32.1)\end{array}$ & $\begin{array}{c}27 \\
(50.9)\end{array}$ & 4.17 \\
\hline Telegram & $\begin{array}{c}36 \\
(67.9)\end{array}$ & $\begin{array}{c}9 \\
(17.0)\end{array}$ & $\begin{array}{c}2 \\
(3.8)\end{array}$ & $\begin{array}{c}4 \\
(7.5)\end{array}$ & $\begin{array}{c}2 \\
(3.8)\end{array}$ & 1.63 \\
\hline Tik Tok & $\begin{array}{c}34 \\
(64.2)\end{array}$ & $\begin{array}{c}5 \\
(9.4)\end{array}$ & $\begin{array}{c}5 \\
(9.4)\end{array}$ & $\begin{array}{c}3 \\
(5.7)\end{array}$ & $\begin{array}{c}6 \\
(11.3)\end{array}$ & 1.91 \\
\hline Snapchat & $\begin{array}{c}39 \\
(73.6)\end{array}$ & $\begin{array}{c}4 \\
(7.5)\end{array}$ & $\begin{array}{c}4 \\
(7.5)\end{array}$ & $\begin{array}{c}2 \\
(3.8)\end{array}$ & $\begin{array}{c}4 \\
(7.5)\end{array}$ & 1.64 \\
\hline Mean of Total & & & & & & 2.37 \\
\hline
\end{tabular}

Table 6. Competency in Social Media

\begin{tabular}{|c|c|c|c|c|c|}
\hline \multirow[t]{2}{*}{ Use of SM } & \multicolumn{4}{|c|}{ Frequency / percentage (\%) } & \multirow[t]{2}{*}{ Mean } \\
\hline & Never & Seldom & Some-times & Always & \\
\hline Facebook & $\begin{array}{c}22 \\
(41.5)\end{array}$ & $\begin{array}{c}11 \\
(20.8)\end{array}$ & $\begin{array}{c}14 \\
(26.4)\end{array}$ & $\begin{array}{c}6 \\
(11.3)\end{array}$ & 2.08 \\
\hline Twitter & $\begin{array}{c}47 \\
(88.7)\end{array}$ & $\begin{array}{c}2 \\
(3.8)\end{array}$ & $\begin{array}{c}3 \\
(5.7)\end{array}$ & $\begin{array}{c}1 \\
(1.9)\end{array}$ & 1.21 \\
\hline WeChat & $\begin{array}{c}44 \\
(83.0)\end{array}$ & $\begin{array}{c}4 \\
(7.5)\end{array}$ & $\begin{array}{c}4 \\
(7.5)\end{array}$ & $\begin{array}{c}1 \\
(1.9)\end{array}$ & 1.28 \\
\hline LINE & $\begin{array}{c}47 \\
(88.7)\end{array}$ & $\begin{array}{c}1 \\
(1.9)\end{array}$ & $\begin{array}{c}3 \\
(5.7)\end{array}$ & $\begin{array}{c}2 \\
(3.8)\end{array}$ & 1.25 \\
\hline Instagram & $\begin{array}{c}21 \\
(39.6)\end{array}$ & $\begin{array}{c}8 \\
(15.1)\end{array}$ & $\begin{array}{c}18 \\
(34.0)\end{array}$ & $\begin{array}{c}6 \\
(11.3)\end{array}$ & 2.17 \\
\hline YouTube & $\begin{array}{c}0 \\
(0.0)\end{array}$ & $\begin{array}{c}7 \\
(13.2)\end{array}$ & $\begin{array}{c}17 \\
(32.1)\end{array}$ & $\begin{array}{c}29 \\
(54.7)\end{array}$ & 3.42 \\
\hline WhatsApp & $\begin{array}{c}5 \\
(9.4)\end{array}$ & $\begin{array}{c}3 \\
(5.7)\end{array}$ & $\begin{array}{c}16 \\
(30.2)\end{array}$ & $\begin{array}{c}29 \\
(54.7)\end{array}$ & 3.30 \\
\hline Telegram & $\begin{array}{c}41 \\
(77.4)\end{array}$ & $\begin{array}{c}4 \\
(7.5)\end{array}$ & $\begin{array}{c}6 \\
(11.3)\end{array}$ & $\begin{array}{c}2 \\
(3.8)\end{array}$ & 1.42 \\
\hline Tik Tok & $\begin{array}{c}33 \\
(62.3)\end{array}$ & $\begin{array}{c}8 \\
(15.1)\end{array}$ & $\begin{array}{c}7 \\
(13.2)\end{array}$ & $\begin{array}{c}5 \\
(9.4)\end{array}$ & 1.70 \\
\hline Snapchat & $\begin{array}{c}41 \\
(77.4)\end{array}$ & $\begin{array}{c}4 \\
(7.5)\end{array}$ & $\begin{array}{c}6 \\
(11.3)\end{array}$ & $\begin{array}{c}2 \\
(3.8)\end{array}$ & 1.42 \\
\hline Mean of Total & & & & & 1.92 \\
\hline
\end{tabular}


Table 6 is used to present the competency of using social media by the respondents. The social media that the respondents are most competent at is YouTube, $\mathrm{M}=4.42$. The percentage of respondents who are very good at using YouTube is $62.3 \%$. The next social media that respondents have high competency level is WhatsApp, $\mathrm{M}=4.17$ with a percentage of $50.9 \%$ respondents who are very good at using it. The three least competent social media are Line $(\mathrm{M}=1.38)$, Twitter $(\mathrm{M}=1.45)$ and WeChat $(\mathrm{M}=1.49)$ which has the least mean in frequency of use as stated in Table 5. The competency levels align with the frequency of social media use. Frequent use could be the reason for respondents to be more competent at using YouTube and WhatsApp as compared to other social media

There are many factors that might influence the use of social media among primary ESL learners. Table 7 shows that $79.2 \%$ respondents use social media to communicate with family. The mean value $(\mathrm{M}=3.02)$ further confirms that most respondents agree that the use social media to communicate with their family. The second highest factor that affects the use of social media with $73.5 \%$ agreeing to it is "to learn new things" $(\mathrm{M}=2.94)$ closely followed by $73.5 \%$ agreeing that they use social media to learn English $(M=2.91)$. These are the three main factors that affect respondents when using social media. The least affected factor would be using SM to do business $(\mathrm{M}=1.58)$. Since this study focuses on primary school students as respondents, it is valid that social media is rarely used as a medium for business purposes at this age.

Item $\mathrm{F} 1$ to $\mathrm{F} 6$ from Table 8 is used to answer research question 1. Item F1 was used to test the comment feature and if students utilize it to learn new vocabulary. From the findings, respondents agree to the fact that they get to learn new vocabulary from the comment sections on social media with $79.3 \%$ agreeing to the statement. Item F2 focused on using "search Google feature" to find the meaning of unknown words. $86.8 \%$ respondents agreed that they use the feature to find meaning of unknown words directly from social media. According to [31] Facebook and other social networks remove limitation of communication between learners that will encourage them to utilize social media helps in a way that they benefit. More than half, $67.9 \%$ respondents agree that they use "spell check" feature available on social media to learn the correct spelling. This is also supported by the related literature [8] where the author mentioned that students prefer learning via social media such as Facebook because of the spell check and grammar check that helps them to correct their mistakes immediately. Cojocnean [37] also revealed that social networking web sites are among the most used digital tools for determining the meaning of a new word.

Item F4 had almost equal percentage of respondents who agrees and disagrees with the use of the feature. Slightly higher percentage of responses were recorded for the disagree part with $50.9 \%$. Despite games being a famous feature of social media, data collected for item F4 shows that most respondents disagree that they get to learn new gaming terms when using social media. This could be due to the internet connectivity problem in certain parts of rural areas as most online games require high speed internet connection. Gender could also be another reason as boys would prefer gaming more than girls do. This is supported by Catalan [36] who concluded that males and females use different types of strategies in learning vocabulary.

Table 7. Factors affecting use of SM

\begin{tabular}{|c|c|c|c|c|c|c|}
\hline \multirow[t]{2}{*}{ Item } & \multirow[t]{2}{*}{ Factors } & \multicolumn{4}{|c|}{$\begin{array}{c}\text { Frequency / } \\
\text { percentage (\%) }\end{array}$} & \multirow[t]{2}{*}{ Mean } \\
\hline & & SD & D & $\mathbf{A}$ & SA & \\
\hline E1 & I use SM to communicate with friends & $\begin{array}{c}17 \\
(32.1)\end{array}$ & $\begin{array}{c}3 \\
(5.1)\end{array}$ & $\begin{array}{c}16 \\
(30.2)\end{array}$ & $\begin{array}{c}17 \\
(32.1)\end{array}$ & 2.62 \\
\hline E2 & I use SM to communicate with family & $\begin{array}{c}10 \\
(18.9)\end{array}$ & $\begin{array}{c}1 \\
(1.9)\end{array}$ & $\begin{array}{c}20 \\
(37.7)\end{array}$ & $\begin{array}{c}22 \\
(41.5)\end{array}$ & 3.02 \\
\hline $\mathbf{E 3}$ & I use SM to learn new things & $\begin{array}{c}8 \\
(15.1)\end{array}$ & $\begin{array}{c}6 \\
(11.3)\end{array}$ & $\begin{array}{c}20 \\
(37.7)\end{array}$ & $\begin{array}{c}19 \\
(35.8)\end{array}$ & 2.94 \\
\hline E4 & I use SM to follow my favourite artiste & $\begin{array}{c}15 \\
(28.3)\end{array}$ & $\begin{array}{c}13 \\
(24.5)\end{array}$ & $\begin{array}{c}14 \\
(26.4)\end{array}$ & $\begin{array}{c}11 \\
(20.8)\end{array}$ & 2.40 \\
\hline E5 & I use SM to learn English & $\begin{array}{c}11 \\
(20.8)\end{array}$ & $\begin{array}{c}3 \\
(5.7)\end{array}$ & $\begin{array}{c}19 \\
(35.8)\end{array}$ & $\begin{array}{c}20 \\
(37.7)\end{array}$ & 2.91 \\
\hline E6 & I use SM to fill my free time & $\begin{array}{c}12 \\
(22.6)\end{array}$ & $\begin{array}{c}5 \\
(9.4)\end{array}$ & $\begin{array}{c}18 \\
(34.0)\end{array}$ & $\begin{array}{c}18 \\
(34.0)\end{array}$ & 2.79 \\
\hline E7 & I use SM to gain knowledge & $\begin{array}{c}15 \\
(28.3)\end{array}$ & $\begin{array}{c}5 \\
(9.4)\end{array}$ & $\begin{array}{c}18 \\
(34.0)\end{array}$ & $\begin{array}{c}15 \\
(28.3)\end{array}$ & 2.62 \\
\hline E8 & I use SM to follow current trend & $\begin{array}{c}11 \\
(20.8)\end{array}$ & $\begin{array}{c}11 \\
(20.8)\end{array}$ & $\begin{array}{c}15 \\
(28.3)\end{array}$ & $\begin{array}{c}16 \\
(30.2)\end{array}$ & 2.68 \\
\hline E9 & I use SM because my friends use it & $\begin{array}{c}23 \\
(43.4)\end{array}$ & $\begin{array}{c}17 \\
(32.1)\end{array}$ & $\begin{array}{c}6 \\
(11.3)\end{array}$ & $\begin{array}{c}7 \\
(13.2)\end{array}$ & 1.94 \\
\hline E10 & I use SM to do business & $\begin{array}{c}35 \\
(66.0)\end{array}$ & $\begin{array}{c}7 \\
(13.2)\end{array}$ & $\begin{array}{c}9 \\
(17.0)\end{array}$ & $\begin{array}{c}2 \\
(3.8)\end{array}$ & 1.58 \\
\hline E11 & I use SM because it is easy to use & $\begin{array}{c}19 \\
(35.8)\end{array}$ & $\begin{array}{c}4 \\
(7.5)\end{array}$ & $\begin{array}{c}15 \\
(28.3)\end{array}$ & $\begin{array}{c}15 \\
(28.3)\end{array}$ & 2.49 \\
\hline E12 & I use SM because it is useful to me & $\begin{array}{c}16 \\
(30.2)\end{array}$ & $\begin{array}{c}5 \\
(9.4)\end{array}$ & $\begin{array}{c}15 \\
(28.3)\end{array}$ & $\begin{array}{c}17 \\
(32.1)\end{array}$ & 2.57 \\
\hline & Mean of Total & & & & & 2.55 \\
\hline
\end{tabular}


Table 8. Ways to improve vocabulary via social media

\begin{tabular}{|c|c|c|c|c|c|c|}
\hline \multirow[t]{2}{*}{ Item } & \multirow[t]{2}{*}{ Ways to improve vocabulary } & \multicolumn{4}{|c|}{ Frequency / percentage (\%) } & \multirow[t]{2}{*}{ Mean } \\
\hline & & SD & $\mathrm{D}$ & A & SA & \\
\hline F1 & Learn new vocabulary from comments/replies & $\begin{array}{c}5 \\
(9.4)\end{array}$ & $\begin{array}{c}6 \\
(11.3)\end{array}$ & $\begin{array}{c}26 \\
(49.1)\end{array}$ & $\begin{array}{c}16 \\
(30.2)\end{array}$ & 3.00 \\
\hline $\mathbf{F} 2$ & learn meaning of words using "search google for" feature & $\begin{array}{c}4 \\
(7.5)\end{array}$ & $\begin{array}{c}3 \\
(5.7)\end{array}$ & $\begin{array}{c}20 \\
(37.7)\end{array}$ & $\begin{array}{c}26 \\
(49.1)\end{array}$ & 3.28 \\
\hline F3 & learn correct spelling via "spell check" feature in SM & $\begin{array}{c}8 \\
(22.6)\end{array}$ & $\begin{array}{c}9 \\
(18.9)\end{array}$ & $\begin{array}{c}17 \\
(32.1)\end{array}$ & $\begin{array}{c}19 \\
(35.8)\end{array}$ & 2.70 \\
\hline F4 & learn new gaming terms via SM & $\begin{array}{c}13 \\
(24.5)\end{array}$ & $\begin{array}{c}14 \\
(26.4)\end{array}$ & $\begin{array}{c}14 \\
(26.4)\end{array}$ & $\begin{array}{c}12 \\
(22.6)\end{array}$ & 2.47 \\
\hline F5 & $\begin{array}{c}\text { use the words learnt via SM when communicating with } \\
\text { others }\end{array}$ & $\begin{array}{c}14 \\
(26.4)\end{array}$ & $\begin{array}{c}7 \\
(13.2)\end{array}$ & $\begin{array}{c}16 \\
(30.2)\end{array}$ & $\begin{array}{c}16 \\
(30.2)\end{array}$ & 2.64 \\
\hline F6 & use the words learnt via SM in my written work & $\begin{array}{c}5 \\
(9.4)\end{array}$ & $\begin{array}{c}9 \\
(17.0)\end{array}$ & $\begin{array}{c}24 \\
(45.3)\end{array}$ & $\begin{array}{c}15 \\
(28.3)\end{array}$ & 2.92 \\
\hline F7 & use internet slang words in writing & $\begin{array}{c}17 \\
(32.1)\end{array}$ & $\begin{array}{c}11 \\
(20.8)\end{array}$ & $\begin{array}{c}15 \\
(28.3)\end{array}$ & $\begin{array}{c}10 \\
(18.9)\end{array}$ & 2.34 \\
\hline F8 & use abbreviation used in SM in writing & $\begin{array}{c}19 \\
(35.8)\end{array}$ & $\begin{array}{c}13 \\
(24.5)\end{array}$ & $\begin{array}{c}15 \\
(28.3)\end{array}$ & $\begin{array}{c}6 \\
(11.3)\end{array}$ & 2.15 \\
\hline F9 & $\begin{array}{c}\text { Feel encouraged when I get to use new words learnt } \\
\text { through SM }\end{array}$ & $\begin{array}{c}10 \\
(18.9)\end{array}$ & $\begin{array}{c}8 \\
(15.1)\end{array}$ & $\begin{array}{c}17 \\
(32.1)\end{array}$ & $\begin{array}{c}18 \\
(33.9)\end{array}$ & 2.65 \\
\hline F10 & Prefer learning new words via SM than in class & $\begin{array}{c}14 \\
(26.4)\end{array}$ & $\begin{array}{c}4 \\
(7.5)\end{array}$ & $\begin{array}{c}17 \\
(32.1)\end{array}$ & $\begin{array}{c}18 \\
(34.0)\end{array}$ & 2.74 \\
\hline & Mean of Total & & & & & 2.69 \\
\hline
\end{tabular}

Item $\mathrm{F} 5$ shows $60.4 \%$ agrees that they get to use the words learnt when communicating with others and $73.6 \%$ agrees that they use the words learnt in their written work. Looking at the results obtained as a whole, respondents agree that they use most of the features available on social media in developing their vocabulary. Other related findings show that social media plays significant role in building students' vocabulary [7]. Analysis of item F5 and F6 shows that students use the words learnt in their daily communication and written works. This contradicts the findings from study conducted by Dehghan et. al. [6] whereby the author says there was no significant improvement in vocabulary development as the participants were attracted to distracters such as chatting. The argument can be further strengthened with the support from Table 7, Item E2 whereby students use social media to communicate with family and item E5, to learn English. Assuming the preferred medium of communication is chatting, as students' preferred choice of social media is WhatsApp (Table 5), the use of chatting as a mean of communication might be one of the reasons on why students get to learn new vocabulary. Consequently, educators should utilize the chatting rather than categorizing it as a distractor. Item F5 also shows that most students use the words learnt when they communicate with others as state in [9] chatting helps students to improve their vocabulary in a non-threatening way.

Item F7 and F8 were created to answer research question 2 , which was to find out the challenges faced by students when using social media to learn vocabulary. There were two main challenges mentioned in previous researches $[22,25]$. One of the mistakes is the use of wrong spelling and short forms in writing. However, $52.9 \%$ respondents of this study disagree about the statement (F7) which says social media users use internet slang words in writing. The percentage of respondents who agreed and disagreed to this statement was almost equal but the frequency of respondents disagreeing with the statement is higher than the ones who agree. This proves that most respondents do not use wrong spelling or short forms in writing even when they use social media actively.

Item $\mathrm{F} 8$ focuses on the use of abbreviation in writing and $60.3 \%$ respondents disagree on the statement. Even though the results obtained favors positively to the research conducted but both, item F7 and F8 did not differ greatly in terms of the percentage of students who agree and disagree. This calls for further research focusing on challenges of using social media to further clarify the challenges faced by primary ESL learners when using social media to learn vocabulary.

Item F9 and F10 were built to answer research question 3, to check if social media acts as the motivation factor in learning vocabulary. $66 \%$ agree that they feel encouraged when they get to use the words learnt from social media and $66.1 \%$ agreed that they prefer learning new words via social media rather than face-to-face context. The findings can be compared with a previous study conducted by Kabilan et. al [9]. The participants felt more confident and motivated when using social media to learn vocabulary. This is in line with Krashen's Affective Filter hypothesis, hence proving that social media can lower one's affective filter and create a better environment for vocabulary development to take place. Thus, interactive computer applications and simulation exercise can be used to supplement the traditional study preparation [32].

Overall, the result of this study shows that the respondents, from primary ESL learners from rural area utilize social media to learn new vocabulary and they feel motivated and encouraged when using social media as medium of developing vocabulary. The limitation of this study is the number of participants involved is less. As for further research, the focus can be given on selected features on social media such as comments and spell-check. 


\section{Conclusions}

To conclude, using social media to develop vocabulary has received positive feedback from the participants. The use of social media serves as an interactive tool that helps ESL learners to learn subconsciously. Therefore, computer applications here can be used as a supplement in order to improvise the traditional teaching and learning method. Suggestion would be to increase the number of respondents and focus on selected parts of social media rather than a general study and look into the teachers' point of view in using Social media as a medium of instruction.

\section{Acknowledgments}

We are very grateful to experts for their appropriate and constructive suggestions to improve this template and the support from administrators of Sekolah Kebangsaan Batu Kikir, Negeri Sembilan for allowing the researcher to collect data from their school.

\section{REFERENCES}

[1] Yunus, M. M., \& Salehi, H. (2012). The Effectiveness of Facebook Groups on Teaching and Improving Writing: Students' Perceptions. International Journal of Education and Information Technology. 1(6), 87-96.

[2] Khurana, N. (2015). The Impact of Social Networking Sites on the Youth. Journal of Mass Communication and Journalism. 5(285). doi:10.4172/2165-7912.1000285

[3] Amedie, J. (2015), The Impact of Social Media on Society. Advanced Writing: Pop Culture Intersections. http://scholarcommons.scu.edu/engl_176/2

[4] Mensah, S., \& Nizam, I. (2016). The Impact of Social Media On Students' Academic Performance - A Case of Malaysia Tertiary Institution. International Journal of Education, Learning and Training, 1(1), 14-21.

[5] Yunus, M. M. \& Salehi, H., Shojaee, M., Fei, Y. W. (2016). Activities and Suggestions for Using Social Networking in Teaching ESL Writing. Journal of Theoretical and Applied Information Technology. 84 (2),170-182.

[6] Dehghan.F., Rezvani, R., Fazeli, S. A. (2015). Social Network and Their Effectiveness in Learning Foreign Language Vocabulary: A Comparative Study Using Whatsapp. Computer Assisted Language LearningElectronic Journal, 18(2), 1-13.

[7] Jafari, S., \& Chalak, A. (2016). The Role of Whatsapp in Teaching Vocabulary to Iranian EFL Learners at Junior High School. English Language Teaching, 9(8), 85-92.

[8] Vikneswaran, T., \& Krish, P. (2015). Utilising Social Networking Sites to Improve Writing: A Case Study with Chinese Students in Malaysia. Technology, Pedagogy and Education, 287-300.10.1080/1475939x.2015.1030441

$25(3)$

[9] Kabilan, M. K., Zalina, T. \& Zahar, M. E. (2016). Enhancing Students' Vocabulary Knowledge Using the Facebook Environment. Indonesian Journal of Applied Linguistics, 5 (2), 217-230.
[10] Greenhow, C. \& Lewin, C. (2016). Social Media and Education: Reconceptualizing The Boundaries of Formal and Informal Learning, Learning, Media and Technology, 41(1), 6-30. DOI: $10.1080 / 17439884.2015 .1064954$

[11] Mahalingam, K. \& Yunus, M. M. (2017). Good Language Learners and Their Strategies: An Insight. Proceedings of the ICECRS. 1(1). 359-366. 10.21070/picecrs.v1i1.504

[12] Krashen, S. (1981). Second Language Acquisition and Second Language Learning. Oxford: Pergamon Press.

[13] Beck, I. L., McKeown, M. G. \& Kucan, L. (2013). Bringing Words to Life: Robust Vocabulary Instruction. The Guilford Press: New York: USA.

[14] Hairrell, A., Rupley, W.\& Simmons, D. (2011). The State of Vocabulary Research. Literacy Research and Instruction. $50(4)$,

253-271.http://dx.doi.org/10.1080/19388071.2010.514036

[15] Unrau, N. J., Alvermann, D. E. (2013). Literacies and Their Investigation Through Theories and Models in Theoretical Models and Processes of Reading. International Reading Association. Newark: USA. 47-90. 10.1598/0710.02.

[16] Faizi, R., Afia, A. E., \& Chiheb, R. (2013). Exploring The Potential Benefits of Using Social Media in Education. International Journal of Engineering Pedagogy (iJEP), 3(4), 50. 10.3991/ijep.v3i4.2836

[17] Al-Mukhaini, E. M., Al-Qayoudhi, W. S., \& Al-Badi, A. H. (2014). Adoption of Social Networking in Education: A Study of the Use Of Social Networks By Higher Education Students In Oman. Journal of International Education Research (JIER), 10(2), 143. 10.19030/jier.v10i2.8516

[18] Hamakali, H.P.S. (2017). Krashen's Theory of Second Language Acquisition as a Framework for Integrating Social Networking in Second Language Learning. Journal of Educational Research. 2(2). 203-216.

[19] Englander, F., Terregrossa, A. R. \& and Wang, Z. (2010). Internet Use Among College Students: Toll or Toy. Educational Review-EDUC-REV. 62(1), 85 -96. 10.1080/00131910903519793.

[20] Roopchund, R., Ramesh, V., \& Jaunky, V. (2019). Use of Social Media for Improving Student Engagement at Université des Mascareignes (UDM). Proceedings of Fifth International Conference India 2018, 2, 11-20. 10.1007/978-981-13-3338-5_2

[21] Asgari, A. \& Mustapha, G. (2011). The Influence of Informal Language Learning Environment (Parents and Home Environment) on the Vocabulary Learning Strategies. English Language and Literature Studies, 1(1). 7-13.10.5539/ells.v1n1p7

[22] James, L. (1995). Sociocultural Theory and Second Language Acquisition. Annual Review of Applied Linguistics. 15, 108 124. $10.1017 / \mathrm{S} 0267190500002646$.

[23] Kimemia, K. A. (2016). Social Media and Teenage Pregnancy among Students in Secondary Schools inImenti North Sub-County, Meru County, Kenya. International Journal of Scientific Research and Management. $10.18535 / \mathrm{ijsrm} / \mathrm{v} 4 \mathrm{i} 9.18$

[24] Wamba, F. S. \& Lemuria, C. (2016). Social Media Tools Adoption and Use by SMES: An Empirical Study.Journal of Organizational and End User Computing (JOEUC). 26. 1-17. 10.4018/joeuc.2014040101. 
[25] Cabrera, L. (2018). Impact of Social Media in English Language Learning: Utilizing S.W.O.T Analysis. Basic Education Research Fund (BERF), 1-26.

[26] Alkurtehe, K. A., \& Dzakiria, H. (2018). An Over review of the Sociocultural Theory and Vocabulary Development. Journal of English Educators Society, 3(1), 41. 10.21070/jees.v3i1.1227

[27] Alqahtani, M. (2015). The Importance of Vocabulary in Language Learning and How to be taught. International Journal of Teaching and Education, 3, 21-34. 10.20472/TE.2015.3.3.002.

[28] Tehranian, Y. (2013). Social Media, Social Kids: Sociocultural Implications of 21st Century Media for Development in the Preteen Period. UCLA Electronic Thesis and Dissertation.

[29] Murayama, K., Kitagami, S., Tanaka, A., \& Raw, J. A. L. (2016). People's Naiveté About How Extrinsic Rewards Influence Intrinsic Motivation. Motivation Science, 2(3), 138-142. 10.1037/mot0000040

[30] Inzamul, H. (2017). English Used in Social Media and Its Effect on the HSC Level Learners. Retrieved from. https://www.academia.edu/38299272/English_Used_in Social Media and Its Effect on the HSC Level Leares

[31] Derakhshan, A., \& Hasanabbasi, S. (2015). Social Networks for Language Learning. Theory and Practice in Language Studies, 5(5), 1090.

[32] Yunus, M, M. (2007). Malaysian ESL Teachers' Use of ICT in Their Classrooms: Expectations and Realities. European Association Computer Assisted Language Learning ReCALL, 9(1), 79-95

[33] Yunus, M. M., Nordin, N., Salehi, H., Embi, M. A., \& Salehi, Z. (2014). Future of ICT as a Pedagogical Tool in ESL Teaching and Learning. Research Journal of Applied Sciences, Engineering and Technology, 7(4), 764-770. 10.19026/rjaset.7.314

[34] Bytheway, J. (2014). In-Game Culture Affects Learners' use of Vocabulary Learning Strategies in Massively Multiplayer Online Role-Playing Game. International Journal of Computer Assisted Language Learning and Teaching. 4(4), 1-13. 10.4018/ijcallt.2014100101

[35] Orsini-Jones, M., Brick, B. \& Pibworth, L. (2013). Practicing Language Interaction via Social Networking Sites: The Expert Student's Perspective on Personalised Language Learning. Journal of Computer Assisted Language Learning and Teaching. 40-53. 10.4018/978-1-4666-2821-2.ch003

[36] Catalán, R.M. (2003). Sex differences in L2 vocabulary learning strategies.International Journal of Applied Linguistics, 13 (1), 54-77.

[37] Cojocnean, D. M. (2015). The vocabulary learning behavior of Romanian high school students in a digital context. (Doctoral Dissertation). University of Exeter. Retrieved from http://hdl.handle.net/10871/18199

[38] Schmitt, N. (2000). Vocabulary in language teaching. Cambridge: Cambridge University Press.

[39] Hunt, A., \& Beglar, D. (1998). The Language Teacher Online: Hunt, $\quad 01 \quad-\quad 1998 . \quad$ Retrieved fromhttp://jalt-publications.org/old_tlt/articles/1998/01/hunt 